\title{
Nota dos Editores
}

\section{Anselmo Gomes de OLIVEIRA; Dâmaris SILVEIRA Editores}

Com o presente número de Infarma - Ciências Farmacêuticas, encerramos o volume 26 de nosso periódico para o ano de 2014. Foi um ano de muito trabalho, mas muito compensador, pois a maior parte das modificações estruturais e de gerenciamento on line das submissões do periódico pôde ser concluída. A responsabilidade ética dos editores do periódico, com relação à avaliação das submissões por pares, levou à formação de uma equipe de 30 editores associados, tanto do Brasil e como do exterior, representativos das várias áreas das Ciências Farmacêuticas.

De outro lado, o periódico teve um reconhecimento inestimável dos assessores "ad hoc" os quais se disponibilizaram para o trabalho e tiveram o importante papel na análise detalhada e criteriosa de cada artigo publicado. A eles nosso profundo reconhecimento e agradecimento, porque esse trabalho garantiu a tramitação dos artigos de forma favorável, assim como resultou na melhoria da qualidade dos textos que foram apresentados.

Os temas que foram veiculados no periódico refletem diretamente a amplitude do conhecimento na área das Ciências Farmacêuticas e suas tendências, passando por abordagens importantes, como metodologias farmacêuticas, análise de perfis de medicamentos, propaganda e logística em medicamentos, farmacovigilância, farmacocinética, farmacoterapia, aspectos da legislação, como análise de rótulos, análise de bulas e de prescrição em medicamentos, interações medicamentosas e interações de fármacos com alimentos, controle da qualidade em farmácia e atenção farmacêutica.
Os artigos publicados em Infarma - Ciências Farmacêuticas têm sido acessados por leitores de todos os continentes, o que mostra o interesse de pesquisadores estrangeiros nos trabalhos realizados em nosso país.

Aos autores e coautores, os colaboradores que confiaram o resultado de seus trabalhos ao periódico Infarma - Ciências Farmacêuticas, nossos sinceros agradecimentos e esperamos que continuemos merecendo essa confiança para o próximo ano. Esses colaboradores são representativos de quase todas as regiões de nosso país, mostrando que a criatividade é uma característica regional, mas que está homogeneamente distribuída em nosso País.

Além disso, no ano que se encerra, também pudemos publicar um suplemento contendo os abstracts Coi$\mathrm{ffa}$, originários da $\mathrm{V}$ Conferência Ibero-Americana de Faculdades de Farmácia, V Congresso Ibero-Americano de Ciências Farmacêuticas e VIII Conferência Nacional de Educação Farmacêutica. Suplementos como esses são importantes, pois conferem visibilidade aos trabalhos apresentados no evento e permitem um maior acesso a esses textos.

Temos a plena certeza de que o periódico continuará merecendo a credibilidade que recebeu até o momento por parte dos autores. Os editores do periódico e o Conselho Federal de Farmácia agradecem por todas as contribuições que se expressaram de diferentes formas, mas todas contribuindo para a consolidação e para o futuro melhor de Infarma - Ciências Farmacêuticas. 